\title{
Application of Mental Nursing Care on Ny. T With Risk of Violent Behavior At Pemenangan Jiwa Sumatera Foundation
}

\section{Meri Natalia Simare Mare}

\author{
Merrysimaremare122@gmail.com
}

\author{
BAB 1 \\ PENDAHULUAN
}

\subsection{Latar Belakang}

Skizofrenia merupakan sekumpulan sindroma klinik yang ditandai dengan perubahan kognitif, emosi, persepsi dan aspek lain dari perilaku. Skizofrenia merupakan suatu kondisi gangguan psikotik yang ditandai dengan gangguan utama dalam pikiran, emosi dan perilaku yang terganggu, dimana berbagai pemikiran tidak saling berhubungan secara logis, persepsi dan perhatian yang keliru (Makhruzah, Putri, \& Yanti, 2021). Prevalensi yang menderita skizofrenia atau psikosis sebesar $7 \%$ per 1000 dengan cakupan pengobatan 84, $9 \%$ dan gangguan prevalensi mental emosional yang di tunjukan pada usia 15 tahun keatas mencapai 9,8 \% dari jumlah penduduk (Riskesdas, 2018). Penanganan penyakit ini karena jiwa yang tergangangu maka di butuhkan adalah terapi, rehabilitasi serta dengan konseling. Upaya terbesar untuk penangan penyakit gangguan jiwa terletak pada keluarga dan masyarakat, dalam hal ini terapi terbaik adalah bentuk dukungan keluarga dalam mencegah kambuhnya penyakit skizofrenia (Pitayanti, \& Hartono, 2020).

Skizofrenia menimbulkan distorsi pikiran, distorsi persepsi, emosi, dan tingkah laku sehingga pasien dengan skizofrenia memiliki Risiko lebih tinggi berperilaku agresif dimana perubahan perilaku secara dramatis terjadi dalam beberapa hari atau minggu. Pasien skizofrenia sering dikaitkan dengan perilaku kekerasan yang dapat membahayakan diri sendiri maupun 
orang lain ataupun berisiko juga dengan lingkungan sekitarnya, baik secara fisik, emosional, seksual, dan verbal. Berdasarkan data tahun 2017 dengan Risiko perilaku kekerasan sekitar $0,8 \%$ atau dari 10.000 orang menunjukkan Risiko perilaku kekerasan sanggatlah tinggi (Pardede, Siregar \& Hulu, 2020).

Resiko Perilaku Kekerasan merupakan Suatu bentuk perilaku yang bertujuan untuk melukai seseorang secara fisik maupun psikologis. Perilaku kekerasan dapat dilakukan secara verbal, diarahkan pada diri sendiri, orang lain, dan lingkungan. Perilaku kekerasan dapat terjadi dalam 2 bentuk yaitu sedang berlangsung Perilaku Kekerasan atau riwayat Perilaku Kekerasan. Faktor penyebab resiko Perilaku Kekerasan salah satunya adalah situasi berduka yang berkepanjangan dari seseorang karena ditinggal oleh seseorang yang dianggap penting. Jika hal ini tidak terhenti, maka akan menyebabkan perasaan harga diri rendah yang sulit untuk bergaul dengan orang lain (Untari, 2021).

Perilaku kekerasan merupakan salah satu respon terhadap stressor yang dihadapi seseorang. Respon ini dapat menimbulkan kerugian baik kepada diri sendiri, orang lain, maupun lingkungan. Penatalaksanaan atau penanganan yang digunakan untuk mengontrol perilaku kekerasan yaitu dengan cara medis dan non medis. Terapi medis yang dapat diberikan seperti obat antipsikotik adalah Chlorpomazine (CPZ), Risperidon (RSP), haloperidol (HLP), Clozapin dan Trifluoerazine (TFP). Untuk terapi non medis seperti terapi generalis.Tindakan keperawatan yang dapat diajarkan klien perilaku kekerasan antara lainmengajarkan klien untuk mengenal masalah perilaku kekerasan serta mengajarkan meengendalikan amarah kekerasan secara fisik: nafas dalam dan pukul bantal, minum obat, verbal/sosisal: menyatakan secara asertif rasa marahnya, spiritual: beribadah sesuai keyakinan pasien dan terapi aktivitas kelompok (Wulansari \& Sholihah, 2021).

Survei awal pada pembuatan askep pada skizofrenia ini dilakukan di Yayasan Pemenang Jiwa Sumatera. Subjek didalam pembuatan askep ini 
berjumlah satu orang dengan pasien atas nama inisial Ny.T, klien datang ke yayasan di bawa oleh abang klien karena awalnya klien sering marah, membanting barang yang ada di rumah dan didiagnosa dengan risiko perilaku kekerasan. Penyebab Ny.T dijadikan sebagai subjek dikarenakan pasien belum dapat mengontrol emosinya selain dengan minum obat.

\subsection{Rumusan Masalah}

Berdasarkan latar belakang masalah tersebut maka dapat dirumuskan masalah saebagai berikut : Bagaimana Memberikan Asuhan Keperawatan Jiwa Pada Ny. T dengan Risiko Perilaku Kekerasan di Yayasan Pemenang Jiwa Sumatera.

\subsection{Tujuan Penulisan}

Adapun tujuannya sebagai berikut :

\subsubsection{Tujuan Umum}

Penulis mampu memberikan asuhan keperawatan jiwa pada $\mathrm{Ny}$. T dengan Risiko Perilaku Kekerasan di Yayasan pemenang jiwa Sumatera.

\subsubsection{Tujuan Khusus}

1. Mahasiswa mampu mengetahui defenisi, tanda \& gejala, faktor penyebab, mekanisme koping, penatalaksanaanpada pasien dengan Risiko Perilaku Kekerasan

2. Mahasiswa mampu melakukan pengkajian pada pasien dengan Risiko Perilaku Kekerasan

3. Mahasiswa mampu menegakkan diagnosa atau masalah keperawatan pada Ny. T dengan Risiko Perilaku Kekerasan.

4. mampu menetapkan intervensi keperawatan secara menyeluruh pada Ny. T dengan Risiko Perilaku Kekerasan.

5. Mahasiswamampu melakukan tindakan keperawatan yang nyata pada Ny. T dengan Risiko Perilaku Kekerasan.

6. Mahasiswa mampu mengevaluasi sebagai tolak ukur guna menerapkan asuhan keperawatan pada Ny. T dengan Risiko Perilaku Kekerasan. 
7. Mahasiswa mampu mendokumentasikan asuhan keperawatan pada Ny. T dengan Risiko Perilaku Kekerasan.

\subsection{Manfaat}

1. Pasien

Diharapkan tindakan yang telah di ajakarkan dapat di terapkan secara mandiri untuk mengontrol emosi dan untuk mendukung kelangsungan kesehatan pasien.

2. Yayasan Pemenang Jiwa Sumatera

Diharapkan dapat menjadi acuan dalam menanganin atau dalam memberikan pelayanan kepada pasien dengan gangguan jiwa dengan perilaku kekerasan di Yayasan Pemenang Jiwa Sumatera. 


\section{BAB 2 \\ TINJAUAN TEORITIS}

\subsection{Konsep Risiko Perilaku Kekerasan}

\subsubsection{Defenisi}

Risiko Perilaku Kekerasan adalah Suatu bentuk perilaku yang bertujuan untuk melukai seseorang secara fisik maupun psikologis. Perilaku kekerasan dapat dilakukan secara verbal, diarahkan pada diri sendiri, orang lain, dan lingkungan. Perilaku kekerasan dapat terjadi dalam 2 bentuk yaitu sedang berlangsung Perilaku Kekerasan atau riwayat Perilaku Kekerasan. (Untari, 2021).

Risiko Perilaku Kekerasan merupakan perilaku yang memperlihatkan individu tersebut dapat mengancam secara fisik, emosional atau seksual kepada orang lain dan adanya kemungkinan seseorang melakukan tindakan yang dapat mencederai diri sendiri bahkan orang lain dan lingkungan akibat ketidakmampuan mengontrol diri. Bentuk perilaku kekerasan yang dilakukan bisa amuk, bermusuhan yang berpotensi melukai, merusak baik fisik maupun kata-kata (Lovinda, 2021).

Perilaku kekerasan adalah suatu bentuk perilaku yang bertujuan melukai seseorang secara fisik maupun psikologis dapat terjai dalam dua bentuk yaitu saat berlangsung kekerasan atau riwayat perilaku kekerasan. Perilaku kekerasan merupakan respon maladaptif dari marah akibat tidak mampu klien untuk mengatasi strssor lingkungan yang dialaminya (Wulansari \& Sholihah, 2021).

\subsubsection{Faktor Terjadinya Risiko Perilaku Kekerasan}

Faktor terjadinya risiko perilaku kekerasan dibagi menjadi dua, yaitu faktor predisposisi dan faktor presipitasi. Faktor predisposisi yang menyebabkan terjadinya skizofrenia meliputi biologis, psikologis dan sosiokultural, dimana faktor biologis yang mendukung terjadinya skizofrenia adalah genetik, neuroanatomi, neurokimia dan 
imunovirologi, dan faktor presipitasi murupakan faktor stressor yang menjadikan klien mengalami skizofrenia yang terdiri dari faktor biologi, psikologi dan sosiokultural yang mampu menyebabkan risiko perilaku kekerasan, halusinasi dan harga diri rendah (Pardede, Keliat, \& Wardani, 2013).

\section{Faktor Predisposisi}

\section{a. Faktor Biologis}

Berdasarkan teori Faktor biologis/genetik mempunyai peranan dalam terjadinya skizofrenia, meskipun sulit dipisahkan apakah karena faktor genetik atau lingkungan. Faktor biologis yang mendukung terjadinya skizofrenia adalah genetik, neuroanatomi, neurokimia dan imunovirologi (Pardede, Keliat, \& Wardani, 2013).

\section{b. Faktor psikologis}

1) Kehilangan

Kehilangan adalah suatu keadaan dimana seseorang merasa kekurangan atas ketiadaan sesuatu yang tadinya ada. Kehilangan disebabkan oleh berbagai macam yaitu kehilangan orang yang dicintai, barang maupun pekerjaan. Rasa kehilangan akan menyebabkan seseorang merasa cemas hingga mengalami kecemasan yang berlebihan itulah yang akan menyebabkan seseorang mengalami gangguan kejiwaan (Kandar, 2019).

2) Kepribadian

Kepribadian adalah organisasi-organisasi dinamis sistemsistem psikofisik dalam individu yang turut menentukan cara-caranya yang unik/khas dalam menyesuaikan diri dengan lingkungannya. kepribadian adalah sesuatu yang menentukan perilaku dalam ketetapan situasi dan kesadaran jiwa. faktor yang mendukung terjadinya risiko 
perilaku kekerasan yaitu kepribadian tertutup (Kandar, 2019).

\section{c. Faktor sosial budaya}

1) Pekerjaan

Faktor status sosioekonomi yang rendah menjadi penyumbang terbesar adanya gangguan jiwa dan menyebabkan perilaku agresif dibandingkan dengan pada seseorang yang memiliki tingkat perekonomian tinggi. Seseorang yang tidak memiliki pekerjaan mempengaruhi kejadian perilaku kekerasan, masalah status sosioekonomi yang rendah berdampak pada status kesehatan jiwa seseorang dan berpotensi menyebabkan gangguan jiwa dan menyebabkna perilaku agresif atau risiko perilaku kekerasan (Wulansari \& Sholihah, 2021).

2) Pernikahan

Penderita risiko perilaku kekerasan yang dirawat dengan gangguan jiwa memiliki riwayat status perkawinan hampir setengahnya belum menikah atau bercerai. Tidak terpenuhinya atau kegagalan dalam memenuhi tugas perkembangan pada masa perkawinan merupakan stresor bagi individu. Rasa malu dan marah dapat menimbulkan frustasi bagi penderita sehingga mengakibatkan penderita cenderung mengalami perilaku maladaptive (Wulansari \& Sholihah, 2021).

\section{Faktor Presipitasi}

Faktor presipitasi dapat bersumber dari klien, lingkungan atau interaksi dengan orang lain. Kondisi klien seperti kelemahan fisik, keputusasaan, ketidak berdayaan, percaya diri yang kurang dapat menjadi perilaku kekerasan. Demikian pula dengan situasi 
lingkungan yang ribut, padat, kritikan yang mengarah pada penghinaan, kehilangan orang yang dicintai atau pekerjaan dan kekerasan merupakan faktor penyebab lain. Ketika seseorang merasa terancam terkadang tidak menyadari sama sekali apa yang menjadi sumber kemarahannya. Tetapi secara umum, seseorang akan mengerluarkan respon marah apabila merasa dirinya terancam (Makhruzah, Putri, \& Yanti, 2021).

\subsubsection{Tanda Dan Gejala Risiko Perilaku Kekerasan}

Sesuai dengan penelitian yang dilakukan oleh Wardani dan Sari (2018), bahwa pasien yang mengalami resiko perilaku kekerasan memiliki tanda dan gejala seperti fisik (muka merang, tegang, mata melotot, tangan mengepal, dan mondar-mandir), verbal (bicara kasar, suara tinggi, membentak, mengancam, mengumpat kata-kata kotor), perilaku (melempar, memukul, menyerang orang, melukai diri sendiri, orang lain dan amuk agresif), emosi (tidak adekuat, tidak nyaman, rasa terganggu, jengkel, tidak berdaya, bermusuhan, mengamuk, ingin berkelahi, menalahkan dan menuntut) (Wardani \& Sari, 2018).

Tanda dan gejala perilaku kekerasan berdasarkan standar asuhan keperawatan jiwa dengan masalah resiko perilaku kekerasan, (Pardede, 2020) :

1. Subjektif

b. Mengungkapkan perasaan kesal atau marah.

c. Keinginan untuk melukai diri sendiri, orang lain dan lingkungan.

d. Klien suka membentak dan menyerang orang lain.

\section{Objektif}
a. Mata melotot/pandangn tajam.
b. Tangan mengepal dan Rahang mengatup.
c. Wajah memerah. 

d. Postur tubuh kaku.
e. Mengancam dan Mengumpat dengan kata-kata kotor.
f. Suara keras.
g. Bicara kasar, ketus.
h. Menyerang orang lain dan Melukai diri sendiri/orang lain.
i. Merusak lingkungan.
j. Amuk/agresif.

\subsubsection{Rentang Respon Marah}

Adaptif

Asertif

Frustasi

Pasif

Agresif

Amuk

\section{Gambar 2.1 Rentang Respon Marah}

\section{Respon Adaptif}

a. Asertif : Individu dapat mengungkapkan marah tanpa menyalahkan orang lain dan memberikan ketenangan

b. Frustasi : Individu gagal mencapai tujuan kepuasan saat marah dan tidak dapat menemukan alternative (Mulia, 2020).

\section{Respon Maladaptif}

a. Pasif : Individu tidak dapat mengungkapkan perasaan nya.

b. Agresif : Perilaku yang menyertai marah, terdapat dorongan untuk menuntut tetapi masih terkontrol.

c. Kekerasan : Perasaan marah dan bermusuhan yang kuat serta hilang nya control (Mulia, 2020). 


\subsubsection{Mekanisme Koping}

Menurut Dwi \& Arum (2017), Perawat perlu mengidentifikasi mekanisme koping klien, sehingga dapat membantu klien untuk mengembangkan koping yang konstruktif dalam mengekpresikan kemarahannya. Mekanisme koping yang umum digunakan adalah mekanisme pertahanan ego seperti displacement, sublimasi, proyeksi, represif, denial dan reaksi formasi (Dwi \& Arum, 2017).

Perilaku yang berkaitan dengan risiko perilaku kekerasan antara lain:

1. Menyerang atau menghindar

Pada keadaan ini respon fisiologis timbul karena kegiatan system syaraf otonom bereaksi terhadap sekresi epinefrin yang menyebabkan tekanan darah meningkat, takikardi, wajah marah, pupil melebar, mual, sekresi HCL meningkat, peristaltik gaster menurun, kewaspadaan juga meningkat, tangan mengepal, tubuh menjadi kaku dan disertai reflek yang cepat.

2. Menyatakan secara asertif

Perilaku yang sering ditampilkan individu dalam mengekspresikan kemarahannya yaitu dengan perilaku pasif, agresif dan perilaku asertif adalah cara yang terbaik, individu dapat mengekspresikan rasa marahnya tanpa menyakiti orang lain secara fisik maupun psikologis dan dengan perilaku tersebut individu juga dapat mengembangkan diri.

3. Memberontak

Perilaku muncul biasanya disertai kekerasan akibat konflik perilaku untuk menarik perhatian orang lain.

4. Perilaku kekerasan

Tindakan kekerasan atau amuk yang ditujukan akibat konflik perilaku

untuk menarik perhatian orang lain (Kio, Wardana, \& Arimbawa, 2020). 


\subsubsection{Penatalaksanaan}

Penanganan yang dilakukan untuk mengontrol perilaku kekerasan yaitu dengan cara medis dan non medis. Terapi medis yang dapat di berikan kepada pasien yaitu Haloperidol 5 mg (2x1), Trihexyphenidyl $2 \mathrm{mg}$ (2x1), Risperidone $2 \mathrm{mg}$ (2x1), dan Chlorpromazine $1 \mathrm{mg}(1 \mathrm{x} 1)$ (Silvia \& Kartina, 2020). Untuk terapi non medis seperti terapi generalis, untuk mengenal masalah perilaku kekerasan serta mengajarkan pengendalian amarah kekerasan secara fisik : nafas dalam dan pukul bantal, minum obat secara teratur, berkomunikasi verbal dengan baik-baik, spritual : beribadah sesuai keyakinan pasien dan terapi aktivitas kelompok, (Hastuti, Agustina, \& Widiyatmoko 2019).

\subsection{Konsep Asuhan Keperawatan Jiwa}

\subsubsection{Pengkajian Keperawatan}

Pengkajian adalah sebagai dasar utama dari proses keperawatan.

Tahap pengkajian terdiri dari pengumpulan data dan perumusan masalah klien. Data yang dikumpulkan melalui data biologis, psikologis, sosial dan spiritual (Saputri \& Mar'atus, 2021)

\subsubsection{Analisa Data}

Analisa Data Dengan melihat data subyektif dan objektif dapat menentukan permasalahan yang dihadapi pasien. Dan dengan memperhatikan pohon masalah dapat diketahui penyebab, affeck dari masalah tersebut. Dari 12 hasil analisa data inilah dapat ditentukan diagnosa keperawatan (Hasannah, 2019).

\subsubsection{Diagnosa Keperawatan}

Menurut Nadek (2019), Diagnosa keperawatan yang sering muncul pada pasien risiko perilaku kekerasan adalah :

1. Resiko perilaku kekerasan 
2. Harga diri rendah

3. Perubahan Presepsi sensori: Halusinasi

4. Isolasi sosial

5. Berduka disfungsional

6. Koping keluarga inefektif

\subsubsection{Intervensi Keperawatan}

Intervensi pada pasien dengan risiko perilaku kekerasan dapat dilakukan dengan pemberian teknik mengontrol perilaku kekerasan dengan pemberian SP I cara fisik yaitu relaksasi tarik nafas dalam serta penyaluran energi, SP II dengan pemberian obat, SP III verbal atau social, SP IV spiritual. Intervensi tersebut dilakukan kepada pasien lalu pasien diberikan jadwal kegiatan sehari dalam upaya mengevaluasi kemampuan pasien mengontrol perilaku kekerasan pasien (Hasannah, 2019).

\subsubsection{Implementasi Keperawatan}

Implementasi adalah tahapan ketika perawat mengaplikasikan ke dalam bentuk intervensi keperawatan guna membantu klien mencapai tujuan yang telah di tetapkan. Kemampuan yang harus dimiliki oleh perawat pada tahap implementasi adalah kemampuan komunikasi yang efektif, kemampuan utnuk menciptakan saling percaya dan saling membantu, kemampuan melakukan teknik, psikomotor, kemampuan melakukan observasi sistemis, kemampuan memberikan pendidikan kesehatan, kemampuan advokasi dan kemampuan evaluasi (Anggit, 2021).

\subsubsection{Evaluasi Keperawatan}

Evaluasi Keperawatan merupakan proses yang berkelanjutan untuk menilai efek dari tindakan keperawatan pada pasien. Evaluasi dilakukan dengan pendekatan SOAP sebagai berikut, S : Respon 
subjektif pasien terhadap tindakan keperawatan yang telah dilaksanakan, 0 : Respon objektif pasien terhadap tindakan keperawatan yang telah dilaksanakan, A:Analisis terhadap data subjektif dan objektif untuk menyimpulkan apakah masalah masih tetap ada, muncul masalah baru, atau ada data yang kontradiksi terhadap masalah yang ada, dan P : Tindak lanjut berdasarkan hasil analisis respon pasien rencana tindak lanjut dapat berupa hal rencana dilanjutkan (jika masalah tidak berubah) atau rencana dimodifikasi (jika masalah tetap, sudah dilaksanakan semua tindakan terapi hasil belum memuasakan) (Anggit, 2021). 


\section{BAB 3}

\section{TINJAUAN KASUS}

\subsection{Identitas Klien}

$\begin{array}{ll}\text { Inisial } & : \text { Ny. T } \\ \text { Jenis kelamin } & : \text { Perempuan } \\ \text { Umur } & : \text { 52 Tahun } \\ \text { Agama } & : \text { Kristen Protestan } \\ \text { Status } & : \text { Lajang } \\ \text { Tanggal pengkajian } & \text { 05 Maret } 2021 \\ \text { Informant } & : \text { Status klien dan komunikasi dengan klien. }\end{array}$

\subsection{Alasan Masuk Yayasan Pemenang Jiwa}

Alasan klien masuk yayasan pemenangan jiwa adalah klien mengatakan klien sering marah-marah semenjak orang tua nya (ibu nya) meninggal dunia pada tahun 2015. Kalau lagi marah klien sering melempar barang yang ada dirumahnya, klien mengatakan bahwa dia tidak dapat mengontrol emosi nya, bahkan pernah hampir memukul abangnya. Abang dan kakak klien semuanya sudah menikah, dan tidak mampu mengurus klien sehingga klien diantar ke yayasan pemenang jiwa.

\subsection{Faktor Predisposisi}

Klien sebelumnya pernah mengalami gangguan jiwa \pm 10 tahun yang lalu dan pulang kerumah dalam keadaan tenang. Dirumah klien tidak rutin minum obat, tidak mau kontrol ke RSJ sehingga timbul gejala-gejala seperti diatas. Keluarga klien tidak ada yang pernah mengalami gangguan jiwa. Masalah Keperawatan: Resiko Perilaku kekerasan

\subsection{Fisik}

Klien tidak memiliki keluhan fisik, saat dilakukan pemeriksaan tanda-tanda vital, didapatkan hasil TD : 110/80 mmHg ; $\mathrm{N}: 80 \mathrm{x} / \mathrm{i} ; \mathrm{S}: 36,5^{\circ} \mathrm{C} ; \mathrm{P}: 20 \mathrm{x} / \mathrm{i}$. Klien memiliki tinggi badan $158 \mathrm{~cm}$ dan berat badan $62 \mathrm{Kg}$. 


\subsection{Psikososial}

\subsubsection{Genogram}

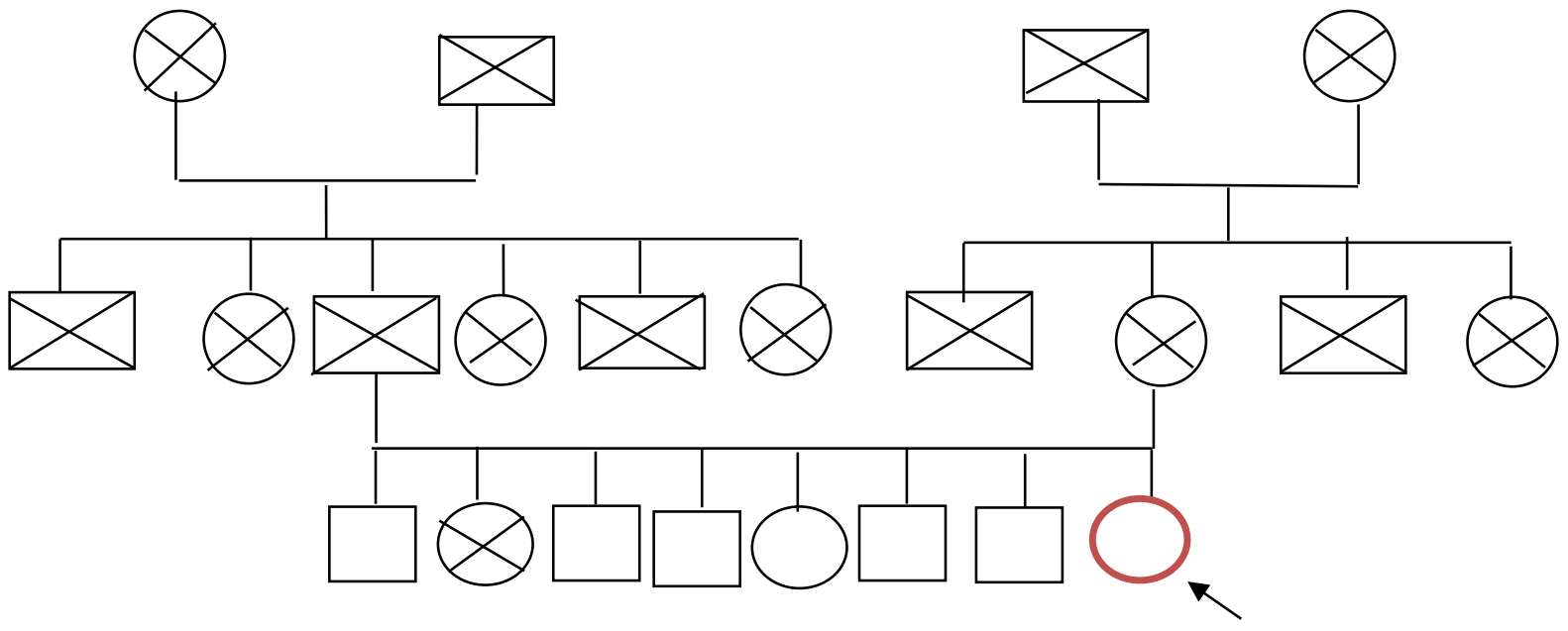

Penjelasan :

Klien anak kedelapan dari 8 bersaudara, klien berinisial Ny. T, anak yatim piatu, ayah dan ibunya meninggal saat usia klien 46 tahun. Ny. T belum menikah.

Keterangan :

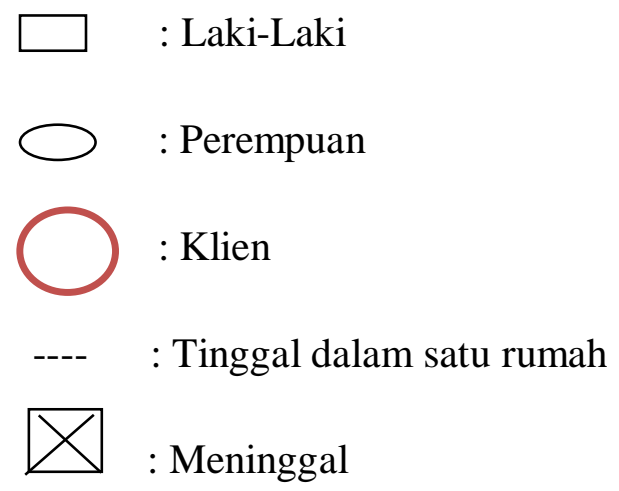

\subsubsection{Konsep diri}

a. Gambaran diri : Tidak ada kecacatan

b. Identitas : Klien anak ke 8 dari 8 bersaudara, klien lulusan S1 Theology yang saat ini dirawat di yayasan pemenang jiwa sumatera

c. Peran : Klien berperan sebagai anak dan masih lajang, klien sebelunya tinggal bersama keluarganya sebelum orang tua nya meninggal dunia. 
d. Ideal diri : Klien merasa malu karena di antarkan ke yayasan pemenangan jiwa tersebut

e. Harga diri : Klien merasa apakah dirinya tidak dianggap oleh saudara nya lagi semenjak orang tua nya meninggal dunia, karena dirinya di tempatkan jauh dari dan abang dan kakaknya

Masalah keperawatan: Gangguan konsep diri : Harga diri rendah

\subsubsection{Hubungan sosial}

Klien mengganggap bahwa keluarganya adalah orang yang sangat berarti dalam hidupnya, orang tua nya sudah meninggal dunia keluarga yang paling berharga adalah abang dan kakaknya. Klien selalu mengikuti kegiatan di yayasan tersebut. Klien mengatakan tidak suka bergaul dengan teman-teman yang ada di yayasan pemenang jiwa, dia lebih suka menyendiri.

Masalah keperawatan: Isolasi sosial

\subsubsection{Spiritual}

1. Nilai dan Keyakinan : Klien beragama kristen dan yakin dengan agamanya.

2. Kegiatan Ibadah $\quad$ : Ibadah 3 kali sehari. Yaitu pagi 2 kali, sekitar pukul 6 pagi dan pukul 10 pagi, selanjutnya jam 7 malam.

\subsubsection{Status Mental}

a. Penampilan

Penjelasan : Klien berpenampilan bersih, dan rapi

b. Pembicaraan

Penjelasan : Klien masih mampu menjawab pertanyaan perawat dengan lambat namun dapat dipahami

c. Aktivitas Motorik

Penjelasan : Klien terlihat sedikit gelisah 
d. Suasana perasaan

Penjelasan : Klien merasa dibuang oleh keluarganya dan merasa minder dengan orang lain karena di rawat diyayasan pemenang jiwa

Masalah keperawatan : Harga Diri Rendah

e. Afek

Penjelasan :Afek klien labil, mudah emosi, mudah marah.

Masalah keperawatan $\quad$ :Risiko perilaku kekerasan

f. Interaksi selama wawancara

Penjelasan : Klien kooperatif, ada kontak mata pada lawan

bicara, mudah tersinggung dalam setiap interaksi.

g. Persepsi

Penjelasan : Tidak mendengar suara-suara aneh

h. Proses Pikir

Penjelasan : Klien mampu menjawab apa yang ditanya dengan baik.

i. Isi piker

Penjelasan : Klien dapat mengontrol isi pikirnya,klien tidak mengalami gangguan isi pikir dan tidak ada waham. Klien tidak

j. Tingkat kesadaran

Penjelasan : Klien tidak mengalami gangguan orientasi, klien mengenali waktu, orang dan tempat.

k. Memori

Penjelasan : Klien mampu menceritakan kejadian di masa lalu dan yang baru terjadi.

1. Tingkat konsentrasi berhitung

Penjelasan : Klien mampu berkonsentrasi dalam perhitungan sederhana tanpa bantuan orang lain.

m. Kemampuan penilaian

Penjelasan : Klien dapat membedakan hal yang baik dan yang buruk.

n. Daya tilik diri 
Penjelasan : Klien tidak mengingkari penyakit yang diderita, klien mengetahui bahwa dia sering marah.

\subsection{Mekanisme Koping}

Klien mengalami mekanisme koping adaptif yaitu klien dapat berbicara baik dengan orang lain dan berkooperatif.

\subsection{Masalah Psikososial Dan Lingkungan}

Masalah dengan dukungan kelompok, spesifik : Pasien megatakan dukungan psikososial dan lingkungan di yayasan sangat baik, hanya saja dia lebih suka menyendiri.

Masalah Keperawatan : Isolasi sosial

\subsection{Pengetahuan Kurang Tentang}

Klien tidak mengetahui tentang gangguan jiwa yang di alaminya, pasien mengatakan jika sedang emosi akan melampiaskannya pada dinding kamar. Masalah Keperawatan : Risiko Perilaku Kekerasan.

\subsection{Aspek Medis}

Diagnosa Medik :

a. Risiko Perilaku Kekerasan

b. Perilaku kekerasan

Terapi Medik : Pemberian/minum obat kepada pasien secara teratur.

a. Risperidon (RSP) tablet $2 \mathrm{mg} 2 \times 1$.

b. Klozapin $25 \mathrm{mg} 2 \times 1$ 


\subsection{Analisis Data}

\begin{tabular}{|c|c|c|}
\hline No & Data & Masalah Keperawatan \\
\hline 1 & $\begin{array}{l}\text { Subjektif: } \\
\text { Klien mengatakan pernah melempar } \\
\text { barang-barang yang ada dirumahnya, } \\
\text { pernah hamper memukul keluarganya dan } \\
\text { marah-marah. } \\
\text { Objektif: } \\
\text { Klien tampak memandang orang lain } \\
\text { dengan tatapan bermusuhan dan tampak } \\
\text { gelisah. }\end{array}$ & $\begin{array}{c}\text { Risiko Perilaku } \\
\text { Kekerasan }\end{array}$ \\
\hline 2. & $\begin{array}{l}\text { Subjektif: } \\
\text { Klien mengatakan tidak mau bergaul dan } \\
\text { lebih suka menyendiri karena penyakitnya. } \\
\text { Objektif: } \\
\text { Klien tampak tidak dapat mempertahankan } \\
\text { kontak mata dengan perawat }\end{array}$ & Isolasi Sosial \\
\hline 3 & $\begin{array}{l}\text { Subjektif: } \\
\text { Klien mengatakan dibuang oleh } \\
\text { keluarganya dan merasa minder dengan } \\
\text { orang lain karena di rawat diyayasan } \\
\text { pemenang jiwa } \\
\text { Objektif : } \\
\text { Klien tampak malu dan gelisah, dan } \\
\text { tampak sedih saat di kaji }\end{array}$ & $\begin{array}{c}\text { Gangguan Konsep Diri } \\
\text { : Harga diri rendah }\end{array}$ \\
\hline
\end{tabular}




\subsection{Pohon Masalah}

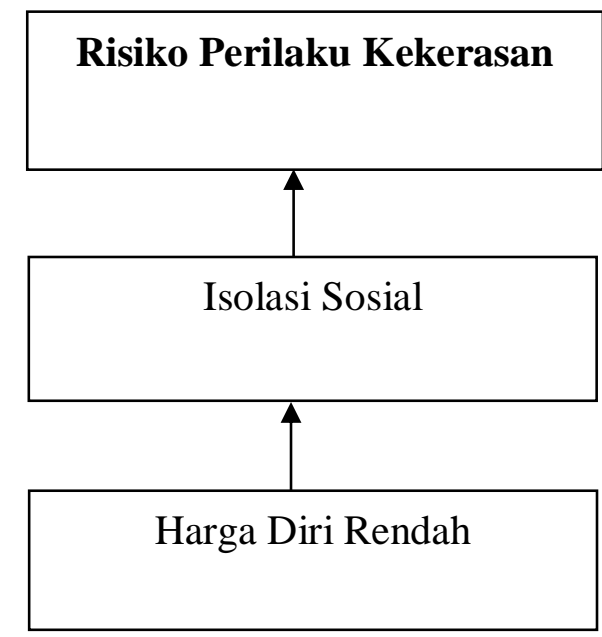

\subsection{Diagnosa Keperawatan}

1. Risiko Perilaku Kekerasan

2. Isolasi Sosial

3. Gangguan Konsep Diri : Harga Diri Rendah 


\subsection{Intervensi Keperawatan}

\begin{tabular}{|c|c|c|c|}
\hline $\begin{array}{l}\text { Diagnosa } \\
\text { Keperawat } \\
\text { an }\end{array}$ & Tujuan & Kriteria Hasil & Intervensi \\
\hline \multirow[t]{3}{*}{$\begin{array}{l}\text { Risiko } \\
\text { perilaku } \\
\text { kekerasan }\end{array}$} & $\begin{array}{l}\text { klien dapat mebina } \\
\text { hubungan saling } \\
\text { percaya }\end{array}$ & $\begin{array}{l}\text { Ketika di evaluasi } \\
\text { Klien mau membalas } \\
\text { salam, berjabat } \\
\text { tangan, menyebutkan } \\
\text { nama, tersenyum, } \\
\text { ada kontak mata, } \\
\text { serta menyediakan } \\
\text { waktu untuk } \\
\text { kunjungan } \\
\text { berikutnya }\end{array}$ & $\begin{array}{l}\text { 1.1. Membina } \\
\text { hubungan } \\
\text { saling } \\
\text { percaya } \\
\text { dengan } \\
\text { cara } \\
\text { (menjelaskan } \\
\text { maksud } \\
\text { dan tujuan } \\
\text { interaksi, } \\
\text { jelaskan } \\
\text { tentang } \\
\text { kontrak yang } \\
\text { akan dibuat, } \\
\text { beri rasa aman } \\
\text { dan sikap } \\
\text { empati) } \\
\text { 1.2. Diskusikan } \\
\text { bersama } \\
\text { klien tentang } \\
\text { perilaku } \\
\text { kekerasan } \\
\text { (penyebab, } \\
\text { tanda dan } \\
\text { gejala, } \\
\text { perilaku yang } \\
\text { muncul dan } \\
\text { akibat dari } \\
\text { perilaku } \\
\text { tersebut). }\end{array}$ \\
\hline & $\begin{array}{l}\text { Klien dapat } \\
\text { mengendalikan } \\
\text { perilaku kekerasan } \\
\text { dengan cara relaksasi } \\
\text { nafas dalam dan } \\
\text { pukul bantal kasur }\end{array}$ & $\begin{array}{l}\text { Klien mampu } \\
\text { menyebutkan dan } \\
\text { menredemonstrasi } \\
\text { kan cara } \\
\text { mengontrol } \\
\text { perilaku kekerasan } \\
\text { dengan cara } \\
\text { relaksasi nafas } \\
\text { dalam dan pukul } \\
\text { bantal }\end{array}$ & $\begin{array}{l}\text { Sp 1 } \\
\text { Latih klien } \\
\text { melakukan } \\
\text { cara } \\
\text { mengontrol } \\
\text { Kemarahan: } \\
\text { 1.3. Ajarkan } \\
\quad \text { tehnik } \\
\quad \text { relaksasi nafas } \\
\text { dalam } \\
\text { 1.4. Pukul bantal }\end{array}$ \\
\hline & Klien dapat & Klien mampu & Sp 2: \\
\hline
\end{tabular}




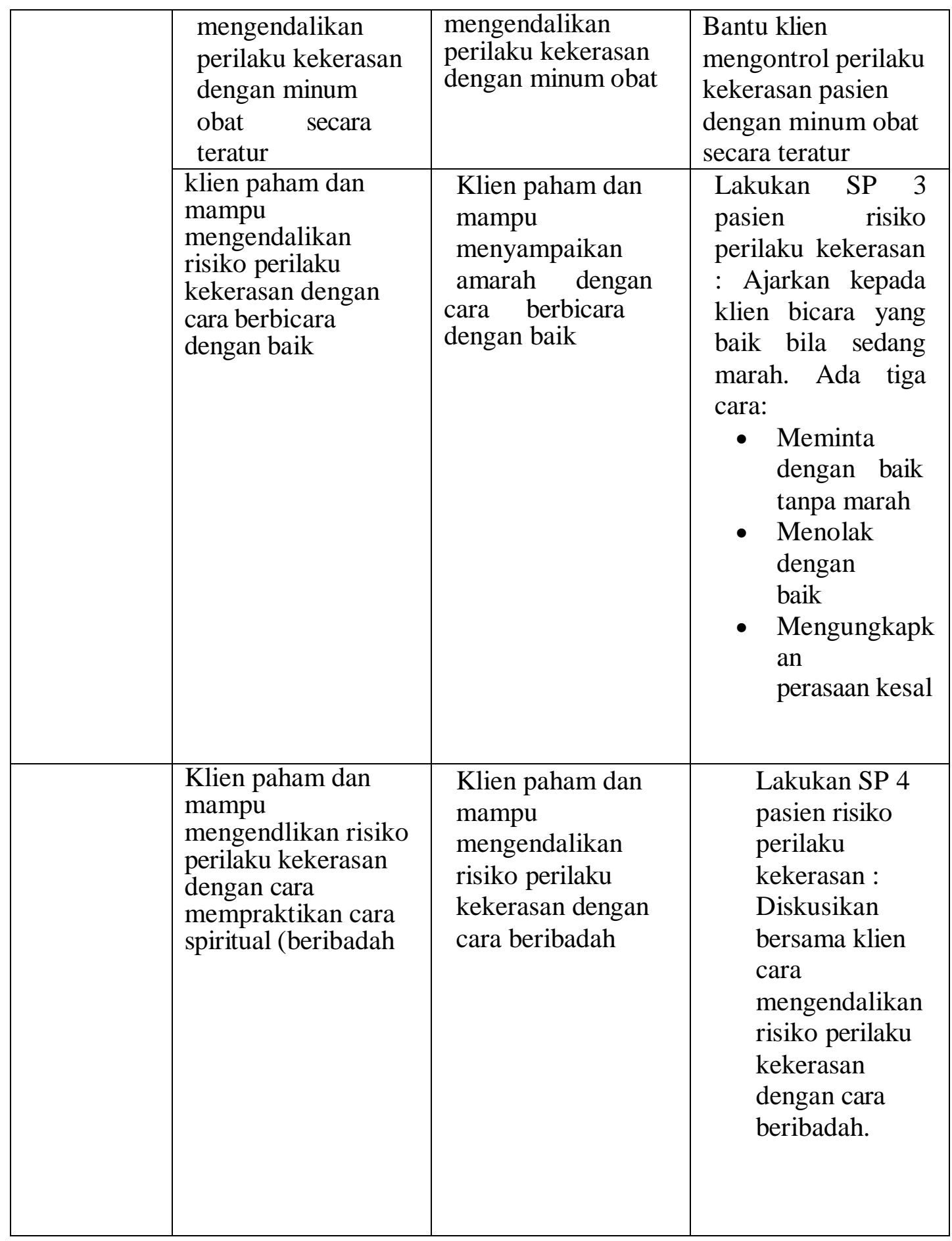




\begin{tabular}{|c|c|c|c|}
\hline $\begin{array}{c}\text { Diagnosa } \\
\text { Keperawat } \\
\text { an }\end{array}$ & Tujuan & Kriteria Hasil & Intervensi \\
\hline $\begin{array}{l}\text { Gangguan } \\
\text { Isi Pikir: } \\
\text { Waham }\end{array}$ & $\begin{array}{l}\text { 1. } \begin{array}{l}\text { Klien dapat } \\
\text { mengetahui } \\
\text { orientasi realita }\end{array} \\
\text { 2. Klien dapat } \\
\text { memanfaatkan } \\
\text { obat dengan baik. } \\
\text { 3. Klien dapat } \\
\text { menyebutkan } \\
\text { keiadian-keiadian } \\
\text { sesuai dengan } \\
\text { urutan waktu serta } \\
\text { harapan/kebutuhan } \\
\text { dasar yang tidak } \\
\text { terpenuhi, seperti : } \\
\text { harga diri, rasa } \\
\text { aman dsb. } \\
\text { 4. Klien memiliki } \\
\text { kemampuan } \\
\text { positif }\end{array}$ & $\begin{array}{l}\text { Ketika di evaluasi : } \\
\text { 1. Klien mampu } \\
\text { mengenal orang, } \\
\text { tempat, dan } \\
\text { waktu serta } \\
\text { lingkungan } \\
\text { sekitar. } \\
\text { 2. Klien dapat } \\
\text { menvebutkan } \\
\text { manfaat minum } \\
\text { obat, kerugian } \\
\text { tidak minum } \\
\text { obat, efek } \\
\text { samping dan } \\
\text { efek terapi. Klien } \\
\text { dapat } \\
\text { mendemonstrasi } \\
\text { kan penggunaan } \\
\text { obat dengan } \\
\text { benar. } \\
\text { Kebutuhan dasar } \\
\text { pasien terpenuhi } \\
\text { klien dapat } \\
\text { melatih } \\
\text { kemampuan } \\
\text { positif yang } \\
\text { dimiliki. }\end{array}$ & $\begin{array}{l}\text { Sp 1: } \\
\text { Latihan orientasi } \\
\text { realita : orientasi } \\
\text { orang, tempat, dan } \\
\text { waktu serta } \\
\text { lingkungan sekitar. } \\
\text { Sp 2: } \\
\text { Minum obat secara } \\
\text { teratur } \\
\text { SP 3: } \\
\text { Melatih cara } \\
\text { pemenuhan } \\
\text { kebutuhan dasar } \\
\text { SP 4: } \\
\text { Melatih kemampuan } \\
\text { positif yang dimiliki }\end{array}$ \\
\hline Isolasi & $\begin{array}{l}\text { Pasien mampu: } \\
\text { 1. Membina } \\
\text { hubungan saling } \\
\text { percaya } \\
\text { 2. Menyadari } \\
\text { penyebab isolasi } \\
\text { Social } \\
\text { 3. Berkenalan } \\
\text { dengan perawat }\end{array}$ & $\begin{array}{l}\text { 1. Mampu } \\
\text { membina } \\
\text { hubungan saling } \\
\text { percaya di tandai } \\
\text { dengan pasien } \\
\text { menunjukkan } \\
\text { ekspresi wajah } \\
\text { bersahabat, } \\
\text { memperlihatkan } \\
\text { rasa senang, ada } \\
\text { kontak mata, } \\
\text { mau berjabat } \\
\text { tangan, mau } \\
\text { menyebutkan } \\
\text { namanya, mau } \\
\text { menjawab salam, }\end{array}$ & $\begin{array}{l}\text { Sp 1: } \\
\text { Menjelaskan } \\
\text { keuntungan dan } \\
\text { kerugian } \\
\text { mempunyai teman } \\
\text { Sp 2: } \\
\text { Melatih klien } \\
\text { berkenalan dengan } \\
2 \text { orang atau lebih } \\
\text { SP 3: } \\
\text { Melatih klien } \\
\text { bercakap-cakap } \\
\text { Sambil melakukan } \\
\text { kegiatan harian }\end{array}$ \\
\hline
\end{tabular}




\begin{tabular}{|c|c|c|c|}
\hline & & $\begin{array}{l}\text { pasien mau } \\
\text { duduk } \\
\text { berdampingan } \\
\text { dengan perawat, } \\
\text { mau } \\
\text { mengutarakan } \\
\text { masalah yang } \\
\text { dihadapi } \\
\text { 2. Mampu } \\
\text { mengenal } \\
\text { penyebab isolasi } \\
\text { sosial, } \\
\text { keuntungan } \\
\text { berhubungan } \\
\text { dengan orang } \\
\text { lain, } \\
\text { kerugian tidak } \\
\text { berhubungan } \\
\text { 3. Mampu } \\
\text { berkenalan } \\
\text { dengan perawat } \\
\text { Mampu } \\
\text { menyusun jadwal } \\
\text { kegiatan harian } \\
\text { berkenalan }\end{array}$ & $\begin{array}{l}\text { SP 4: } \\
\text { Melatih berbicara } \\
\text { sosial : Seperti } \\
\text { meminta sesuatu, } \\
\text { berbelanja, dan } \\
\text { sebagainya }\end{array}$ \\
\hline $\begin{array}{l}\text { Gangguan } \\
\text { Konsep Diri } \\
\text { : Harga Diri } \\
\text { Rendah }\end{array}$ & 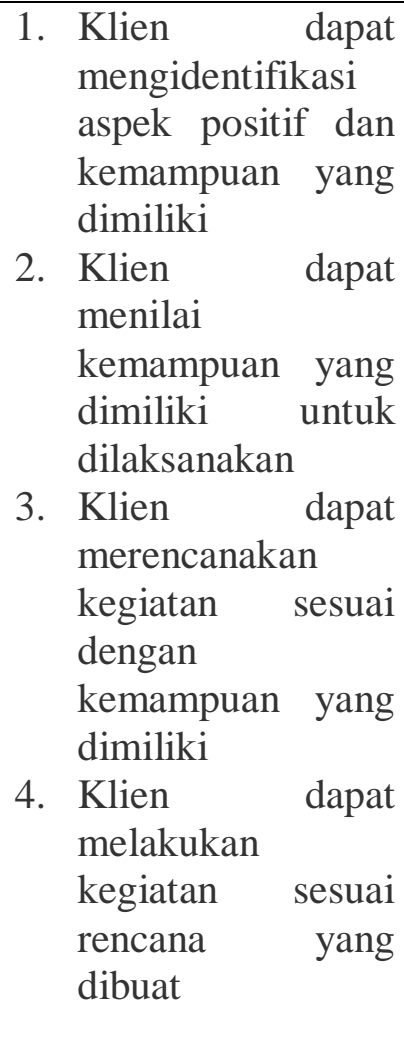 & 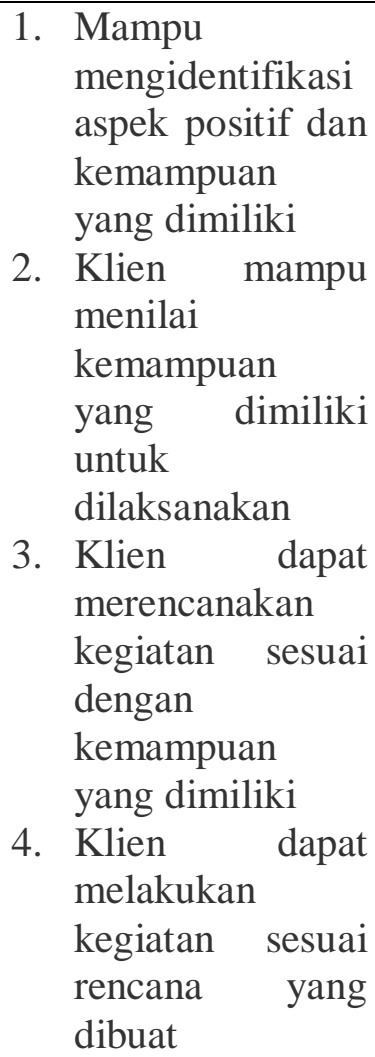 & 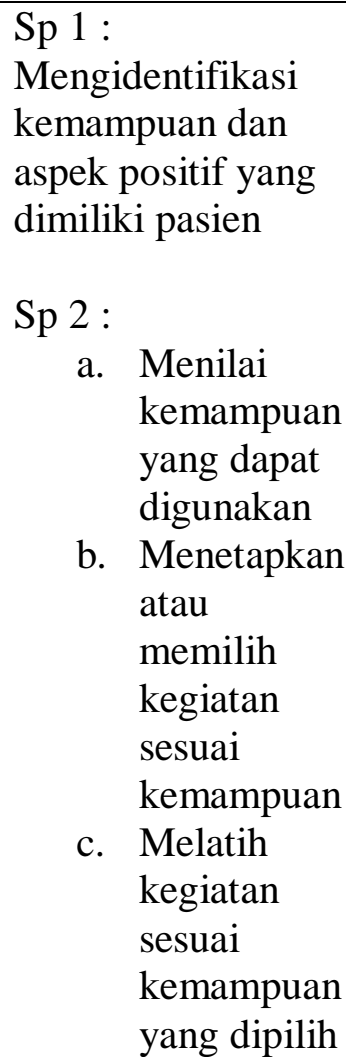 \\
\hline
\end{tabular}




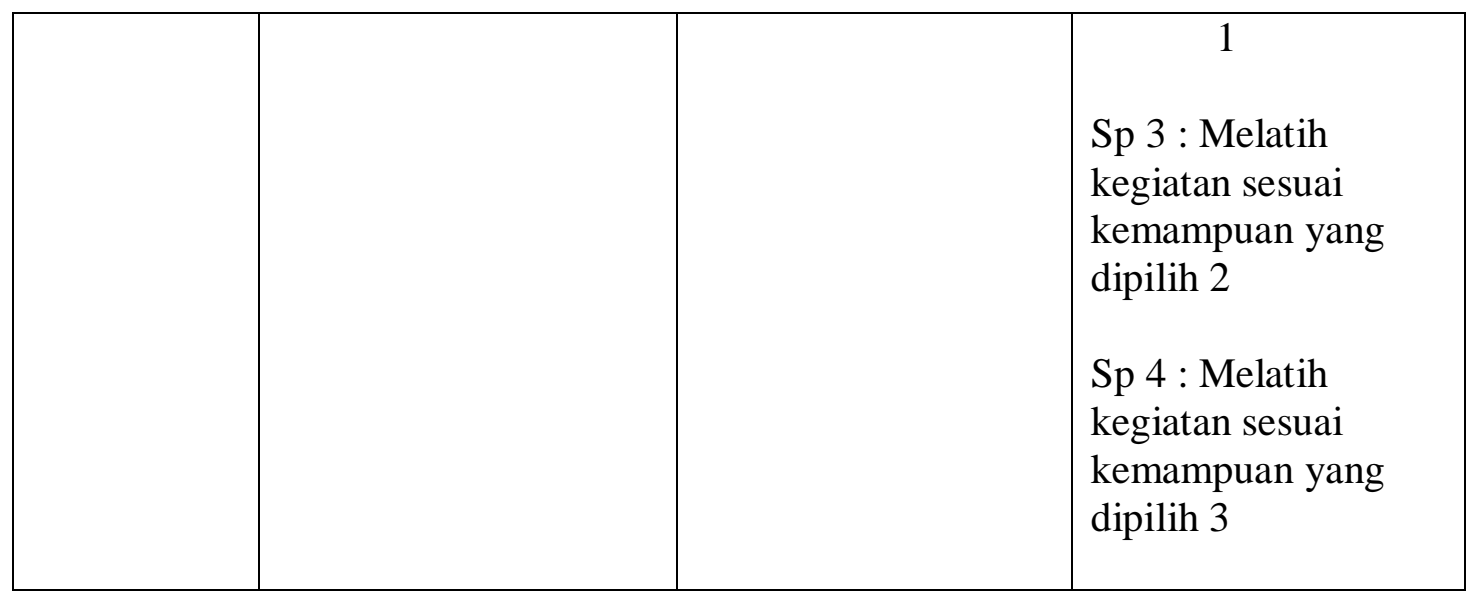


3.14 Implementasi Dan Evaluasi Keperawatan

\begin{tabular}{|c|c|c|}
\hline Hari/tgl & Implementasi & Evaluasi \\
\hline $\begin{array}{l}\text { Selasa, } 09 \\
\text { Maret } 2021 \\
\text { 10:30 WIB }\end{array}$ & $\begin{array}{l}\text { 1. Data : } \\
\text { Tanda dan gejala : mudah marah- } \\
\text { marah, mudah tersinggung,tatapan } \\
\text { sinis, ,suka menyendiri, merasa } \\
\text { tidak dihargai } \\
\text { 2. Diagnosa Keperawatan } \\
\text { Risiko Perilaku Kekerasan } \\
\text { Harga Diri Rendah } \\
\text { 3. Tindakan keperawatan: } \\
\text { Sp } 1 \text { Risiko Perilaku Kekerasan: } \\
\text { - } \text { Mengidentifikasi penyebab risiko } \\
\text { perilaku kekerasan yaitu jika } \\
\text { kemauan klien tidak dituruti } \\
\text { Mengidentifikasi tanda dan gejala } \\
\text { - } \text { Risiko Perilaku Kekerasan: } \\
\text { risiko perilaku kekerasan yaitu } \\
\text { klien marah, mengamuk tanpa } \\
\text { jelas, merusak barang-barang, dan } \\
\text { cenderung melukai orang lain } \\
\text { Menyebutkan cara mengontrol } \\
\text { risiko perilaku kekerasan adalah } \\
\text { dengan latihan fisik } 1 \text { : tarik napas } \\
\text { dalam latihan fisik } 2 \text { : pukul kasur } \\
\text { bantal } \\
\text { Membantu klien latihan tarik } \\
\text { napas dalam dan pukul kasur } \\
\text { bantal. } \\
\text { - }\end{array}$ & 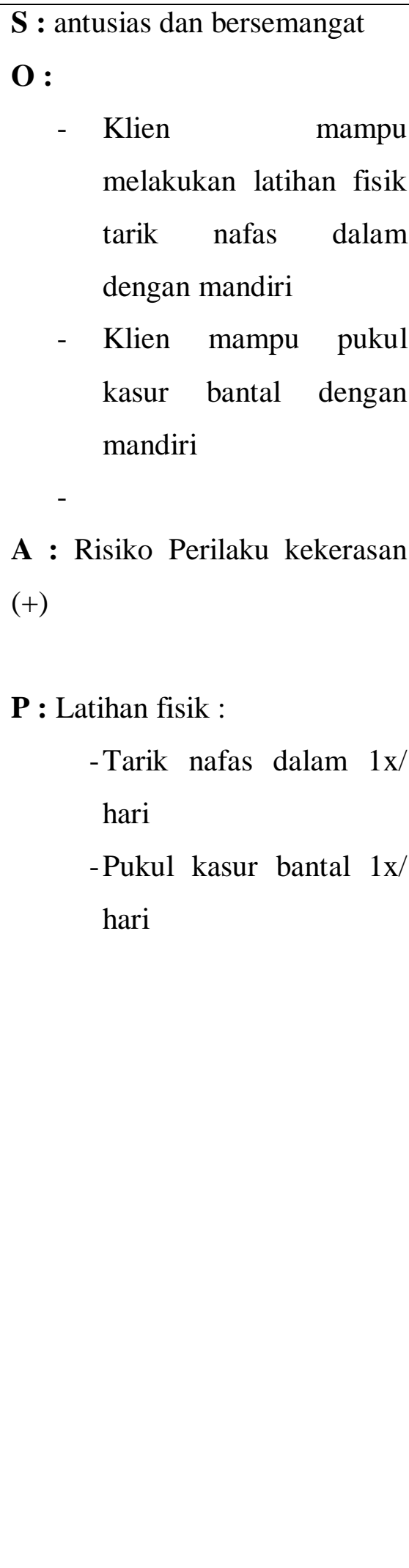 \\
\hline
\end{tabular}




\begin{tabular}{|c|c|c|}
\hline & $\begin{array}{l}\text { kekerasan dengan minum obat } \\
\text { secara teratur }\end{array}$ & \\
\hline $\begin{array}{l}\text { Rabu, } 10 \\
\text { Maret } 2021 \\
\text { 10:00 WIB }\end{array}$ & $\begin{array}{l}\text { 1. Data : } \\
\text { Tanda dan gejala : mudah marah- } \\
\text { marah, mudah tersinggung,tatapan } \\
\text { sinis, merasa tidak dihargai } \\
\text { Kemampuan : berjualan depan } \\
\text { rumah } \\
\text { 2. Diagnosa Keperawatan } \\
\text { Risiko Perilaku Kekerasan } \\
\text { Harga Diri Rendah } \\
\text { 3. Tindakan keperawatan: } \\
\text { Sp 2 Risiko Perilaku Kekerasan } \\
\text { 1. Mengevaluasi kemampuan } \\
\text { klienuntuk tarik nafas dalam } \\
\text { dan pukul kasur bantal } \\
\text { 2. Memberikan informasi tentang } \\
\text { penggunaan obat } \\
\text { 4.RTL: } \\
\text { Sp } 3 \text { Risiko Perilaku Kekerasan } \\
\text { verbal:Asertif/bicara baik-baik. }\end{array}$ & 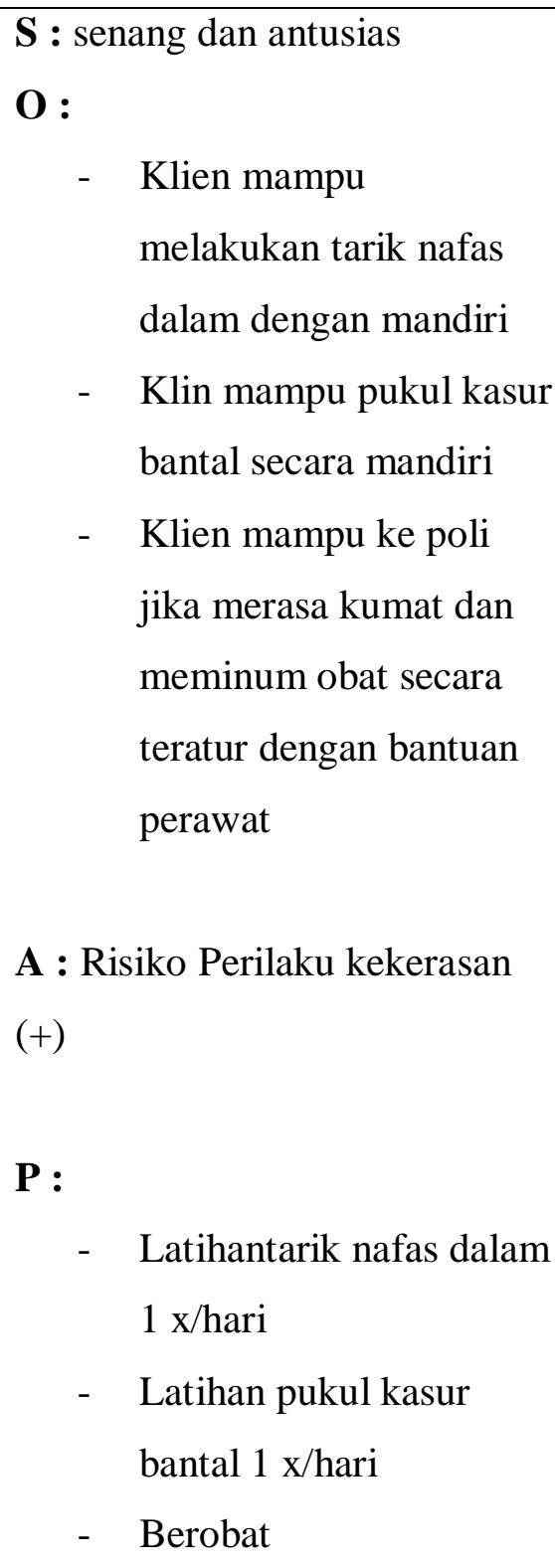 \\
\hline $\begin{array}{l}\text { Jumat, } 12 \\
\text { Maret } 2021 \\
\text { 10:30 WIB }\end{array}$ & $\begin{array}{l}\text { 1. Data: } \\
\text { Tanda dan gejala : mudah marah- } \\
\text { marah, mudah tersinggung,tatapan } \\
\text { sinis, merasa tidak dihargai } \\
\text { Kemampuan : berjualan } \\
\text { 2. Diagnosa Keperawatan: } \\
\text { Risiko Perilaku Kekerasan } \\
\text { Harga Diri Rendah }\end{array}$ & $\begin{array}{l}\text { S : } \text { senang } \\
\text { O : } \\
\text { - } \text { Klien mampu melakukan } \\
\text { komunikasi secara verbal : } \\
\text { asertif/bicara baik- } \\
\quad \text { baikdengan motivasi } \\
\text { A : } \\
\text { (+) }\end{array}$ \\
\hline
\end{tabular}




\begin{tabular}{|c|c|c|}
\hline & $\begin{array}{l}\text { 3. Tindakan keperawatan: } \\
\text { Sp } 3 \text { Risiko Perilaku Kekerasan } \\
\text { - } \quad \text { Mengevaluasi kemampuan klien } \\
\text { untuk tarik nafas dalam dan pukul } \\
\text { kasur bantal } \\
\text { - Minum obat } \\
\text { - Komunikasi secara verbal : } \\
\text { asertif/bicara baik-baik } \\
\text { 4.RTL: } \\
\text { Sp } 4 \text { Risiko Perilaku Kekerasan: } \\
\text { - Spritual : Beribadah }\end{array}$ & $\begin{array}{ll}\text { P : } & \\
\text { - } & \text { Latihan tarik nafas } \\
& \text { dalam dan pukul kasur } \\
& \text { bantal 1x/hari } \\
\text { - } & \text { Berobat } \\
\text { - } & \text { Klien } \quad \\
& \text { komunikasi } \quad \text { secara } \\
& \text { verbal : asertif/bicara } \\
& \text { baik-baik }\end{array}$ \\
\hline $\begin{array}{l}\text { Sabtu, } \\
13 \text { Maret } \\
2021 \\
\text { 10:30 WIB }\end{array}$ & $\begin{array}{l}\text { 1. Data: } \\
\text { Tanda dan gejala : mudah marah- } \\
\text { marah, mudah tersinggung,tatapan } \\
\text { sinis, merasa tidak dihargai } \\
\text { Kemampuan : berjualan } \\
\text { 2. Diagnosa Keperawatan: } \\
\text { Risiko Perilaku Kekerasan } \\
\text { Harga Diri Rendah } \\
\text { 3.Tindakan keperawatan: } \\
\text { Sp } 4 \text { Risiko Perilaku Kekerasan } \\
\text { - Mengevaluasi kemampuan klien } \\
\text { dalam tarik nafas dalam dan } \\
\text { pukul kasur bantal, minum obat } \\
\text { secara teratur dan bicara baik- } \\
\text { baik. } \\
\text { Melatih klien } \\
\text { melaksanakan kegiatan spiritual } \\
\text { yang sudah diatur. } \\
\text { RTL . }\end{array}$ & $\begin{array}{ll}\text { S : } & \text { senang } \\
\text { O : } & \\
& \text { Klien mampu } \\
& \text { melaksanakan kegiatan } \\
& \text { ibadah dengan baik } \\
& \text { misalnya Sholat } \\
\text { A : } & \text { Risiko perilaku kekerasan } \\
(+) & \\
\text { P: } & \\
& \text { Latihantarik nafas dalam } \\
& \text { dan pukul kasur bantal } \\
& \text { 2x/hari } \\
\text { - } & \text { Berobat } \\
\text { - } & \text { Latihan melakukan } \\
& \text { komunikasi secara } \\
& \text { verbal : asertif/bicara } \\
\text { baik-baik } & \text { Latihan klien untuk }\end{array}$ \\
\hline
\end{tabular}




\begin{tabular}{|l|l|l|}
\hline $\begin{array}{l}\text { Risiko Perilaku Kekerasan : Follow up } \\
\text { dan evaluasi SP 1-4 risiko Perilaku } \\
\text { Kekerasan }\end{array}$ & melaksanakan kegiatan \\
& spiritual yang sudah \\
diatur.
\end{tabular}

\begin{tabular}{|c|c|c|}
\hline Hari/tgl & Implementasi & Evaluasi \\
\hline $\begin{array}{l}\text { Selasa, } 16 \\
\text { Maret } 2021 \\
10: 30 \text { WIB }\end{array}$ & 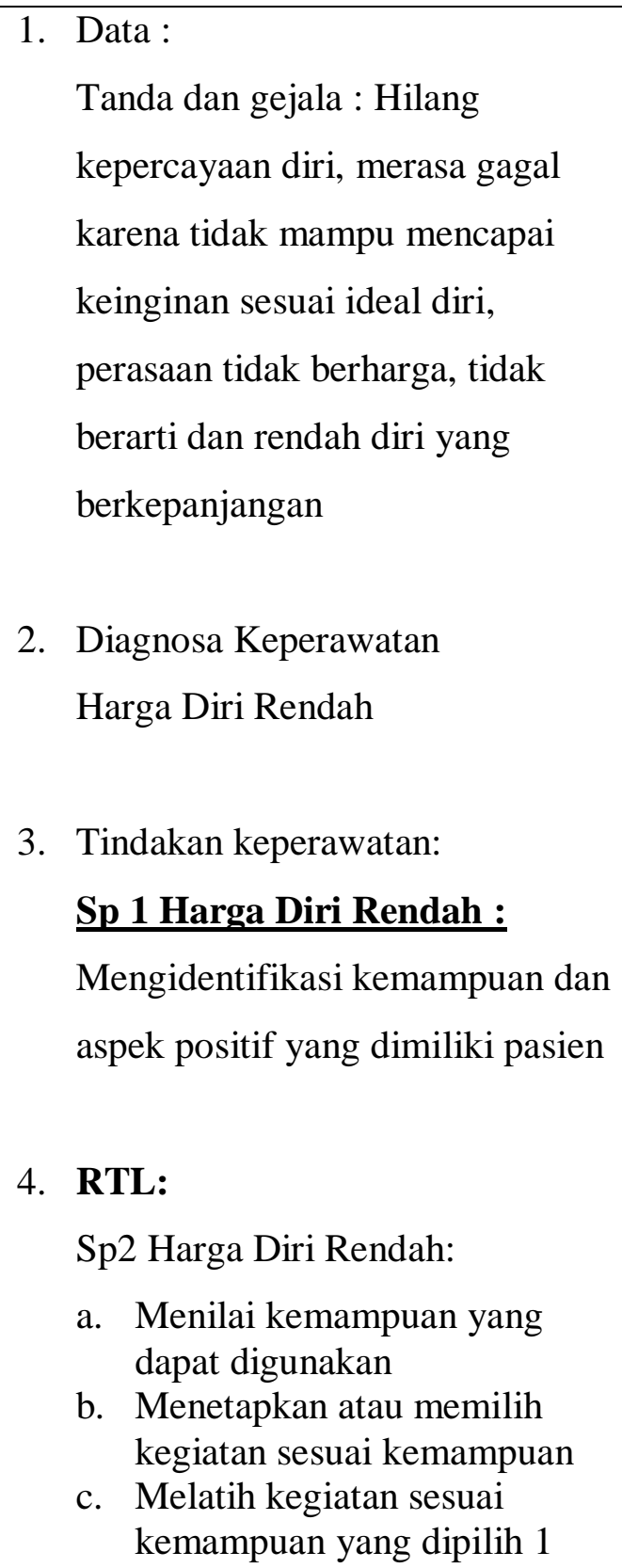 & $\begin{array}{l}\text { S : Antusias dan bersemangat } \\
\text { O : } \text { Klien mampu } \\
\text { Mengidentifikasi aspek } \\
\text { positif yang dimiliki pasien } \\
\text { yaitu berdoa dan bersyukur. } \\
\text { A : Harga Diri Rendah (+) } \\
\text { P : Klien selalu memulai segala } \\
\text { aktivitas nya dengan } \\
\text { bersyukur dan Doa. }\end{array}$ \\
\hline
\end{tabular}




\begin{tabular}{|c|c|c|}
\hline $\begin{array}{l}\text { Kamis, } 18 \\
\text { Maret } 2021 \\
\text { 10:00 WIB }\end{array}$ & $\begin{array}{l}\text { 1. Data : } \\
\text { Tanda dan gejala : Hilang } \\
\text { kepercayaan diri, merasa gagal } \\
\text { karena tidak mampu mencapai } \\
\text { keinginan sesuai ideal diri, } \\
\text { perasaan tidak berharga, tidak } \\
\text { berarti dan rendah diri yang } \\
\text { berkepanjangan } \\
\text { 2. Diagnosa Keperawatan } \\
\text { Harga Diri Rendah } \\
\text { Tindakan keperawatan: } \\
\text { Sp 2 Harga Diri Rendah : } \\
\text { a. Menilai kemampuan yang } \\
\text { dapat digunakan } \\
\text { b. Menetapkan atau memilih } \\
\text { kegiatan sesuai kemampuan } \\
\text { c. Melatih kegiatan sesuai } \\
\text { kemampuan yang dipilih } 1 \\
\text { Sp } 3 \text { : Melatih kegiatan sesuai } \\
\text { kemampuan yang dipilih } 2\end{array}$ & $\begin{array}{l}\text { S : Senang dan antusias } \\
\text { O : } \\
\text { Klien mampu memilih dan } \\
\text { melatih kegiatan sesuai } \\
\text { kemampuan yaitu masak. } \\
\text { A : Harga Diri Rendah (+) } \\
\mathbf{P}: \text { Klien melatih kemampuan } \\
\text { memasak yang dimiliki nya }\end{array}$ \\
\hline $\begin{array}{l}\text { Sabtu, } 20 \\
\text { Maret } 2021 \\
\text { 10:30 WIB }\end{array}$ & $\begin{array}{l}\text { 1. Data: } \\
\text { Tanda dan gejala : Hilang } \\
\text { kepercayaan diri, merasa gagal } \\
\text { karena tidak mampu mencapai } \\
\text { keinginan sesuai ideal diri, } \\
\text { perasaan tidak berharga, tidak } \\
\text { berarti dan rendah diri yang } \\
\text { berkepanjangan }\end{array}$ & $\begin{array}{l}\text { S: Senang dan antusias } \\
\text { O : } \text { Klien mampu melatih } \\
\\
\text { kegiatan sesuai } \\
\text { kemampuan yaitu menyuci } \\
\quad \text { piring. } \\
\text { A : Harga Diri Rendah (+) } \\
\mathbf{P}:\end{array}$ \\
\hline
\end{tabular}




\begin{tabular}{|c|c|c|}
\hline & $\begin{array}{l}\text { 2. Diagnosa Keperawatan } \\
\text { Harga Diri Rendah } \\
\text { 3. Tindakan keperawatan: } \\
\text { Sp } 3 \text { Harga Diri Rendah : } \\
\text { Melatih kegiatan sesuai } \\
\text { kemampuan yang dipilih } 2 \\
\text { 4. RT: } \\
\text { Sp } 4 \text { : Melatih kegiatan sesuai } \\
\text { kemampuan yang dipilih } 3\end{array}$ & $\begin{array}{l}\text { - } \text { Berdoa, Mengikuti } \\
\text { ibadah } \\
\text { - } \text { Membantu Masak } \\
\text { - } \text { Menyuci piring }\end{array}$ \\
\hline $\begin{array}{l}\text { Selasa, } \\
23 \text { Maret } \\
2021 \\
\text { 10:30 WIB }\end{array}$ & $\begin{array}{l}\text { 1. Data : } \\
\text { Tanda dan gejala : Hilang } \\
\text { kepercayaan diri, merasa gagal } \\
\text { karena tidak mampu mencapai } \\
\text { keinginan sesuai ideal diri, } \\
\text { perasaan tidak berharga, tidak } \\
\text { berarti dan rendah diri yang } \\
\text { berkepanjangan } \\
\text { 2. Diagnosa Keperawatan } \\
\text { Harga Diri Rendah } \\
\text { Tindakan keperawatan: } \\
\text { Sp } 4 \text { Harga Diri Rendah : } \\
\text { Melatih kegiatan sesuai } \\
\text { kemampuan yang dipilih } 3 \\
\text { RTL : } \\
\text { evaluasi SP 1-4 }\end{array}$ & $\begin{array}{l}\text { S : Senang } \\
\text { O : Melatih kegiatan sesuai } \\
\text { kemampuan yang dipilih } \\
\text { yaitu menyapu rumah } \\
\text { A : Harga diri rendah (+) } \\
\text { P : } \\
\text { - } \text { Berdoa, } \\
\text { ibadah } \\
\text { - Membantu Masak } \\
\text { - Menyuci piring } \\
\text { - } \text { Menyapu Halaman }\end{array}$ \\
\hline
\end{tabular}




\section{BAB 4 \\ PEMBAHASAN}

Setelah mahasiwa melaksanakan asuhan keperawatan kepada Ny. T dengan Risiko Perilaku Kekerasan di Yayasan Pemenang Jiwa Sumatera, maka mahasiswa pada BAB ini akan membahas kesenjangan antara teoritis dan tinjauan kasus. Pembahasan dimulai melalui tahapan prosess keperawtan yaitu pengkajian, diagnosa keperawatan, perencanaan, pelaksanaan dan evalusi.

\subsection{Tahap Pengkajian}

Selama pengkajian dilakukan pengumpulan data dari beberapa sumber yaitu dari pasien dan pengawas yayasan. Mahasiswa mendapat sedikit kesulitan dalam mmenyimpulkan data kerena keluarga pasien tidak pernah mengkunjungi pasien di yayasan pemenang jiwa. Maka mahasiwa melakukan pendekatan pada pasien melalui komunikasi terapeutik yang lebih terbuka membantu pasien untuk memecahkan perasaannya dan juga melakukan observasi kepada pasien. Adapan upaya tersebut yaitu :

1. Melakukan pendekatan dan membina hubungan saling percaya diri pada pasien agar pasien lebih terbuka dan lebih percaya dengan menggunakan perasaan.

2. Mengadakan pengkajian pasien dengan wawancara dan tidak menemukan kesenjangan karena di temukan hal sama seperti diteori bahwasanya Risiko Perilaku Kekerasan merupakan Suatu bentuk perilaku yang bertujuan untuk melukai seseorang secara fisik maupun psikologis. Perilaku kekerasan dapat dilakukan secara verbal, diarahkan pada diri sendiri, orang lain, dan lingkungan (Untari, 2021).

\subsection{Tahap Perencanaan}

Perencanaan dalam proses keperawatan lebih di kenal dengan asuhan keperawatan yang merupakan tahap selanjutnya setelah pengkajian dan penentuan diagnosa keperawatan. Pada tahap perencanaan mahasiswa 
menyusun rencana tindakan keperawatan Risiko Perilaku Kekerasan, dan Harga Diri Rendah. Pada tahap ini antara tinjauan teroritis dan tinjauan kasus tidak ada kesenjangan sehingga mahasiswa dapat melaksanakan tindakan seoptimal mungkin di dukung dengan seringnya bimbingan dengan pembimbing. Secara teoritis digunakan secara strategi pertemuan sesuai dengan diagnosa keperawatan yang muncul saat pengkajian. Adapun upaya yang digunakan mahasiswa ialah :

\section{Risiko Perilaku Kekerasan}

a. Mengidentifikasikan isi Risiko Perilaku Kekerasan.

b. Mengidentifikasikan waktu terjadi Risiko Perilaku Kekerasan.

c. Mengidentifikasikan situasi pencetus Risiko Perilaku Kekerasan.

d. Mengidentifikasikan respon terhadap Risiko Perilaku Kekerasan.

e. Membantu pasien mempraktekkan latihan cara mengontrol Risiko Perilaku Kekerasan dengan tarik nafas dalam dan pukul bantal.

f. Menjelaskan cara mengontrol Perilaku Kekerasan dengan minum obat secara teratur.

g. Melatih pasien mengotrol Risiko Perilaku Kekerasan dengan berbicara baik-baik dengan orang lain dan spritual.

h. Mengevalusi jadwal kegiatan harian pasien.

2. Harga diri rendah

a. Mengidentifikasi kemampuan dan aspek positif yang dimiliki pasien

b. Menilai kemampuan yang dapat digunakan

1) Menetapkan atau memilih kegiatan sesuai kemampuan

2) Melatih kegiatan sesuai kemampuan yang dipilih 1

c. Melatih kegiatan sesuai kemampuan yang dipilih 2

d. Melatih kegiatan sesuai kemampuan yang dipilih 3

e. Mengevalusi jadwal kegiatan harian pasien.

\subsection{Tahap Implementasi}

Pada tahap implementasi mahasiswa mengatasi masalah keperawatan dengan diagnosa keperawatan Risiko Perilaku Kekerasan/Perilaku 
Kekerasan karena masalah utama yang dialami pasien. Pada diagnosa keperawatan Risiko Perilaku Kekerasan/Perilaku Kekerasan strategi pertemuan ialah mengidentifikasi perilaku kekerasan, mengontrol perilaku kekerasan, dan cara tarik nafas dalam dan pukul bantal kasur. Strategi pertemuan yang kedua ialah anjurkan minum obat secara teratur, strategi pertemuan ketiga ialah latihan cara komunikasi secara verbal atau bicara baik-baik. dan strategi terakhir pertemuan keempat yaitu spiritual (Hasannah, 2019). .

\subsection{Tahap Evaluasi}

Pada tinjauan kasus evaluasi yang dihasilkan adalah :

1. Klien sudah dapat mengontrol dan mengidentifikasi Risiko Perilaku Kekerasan.

2. Klien dapat mengendalikan Risiko Perilaku Kekerasan melalui latihan fisik.

3. Klien dapat mengendalikan Risiko Perilaku Kekerasan dengan minum obat secara teratur.

4. Klien dapat mengendalikan Risiko Perilaku Kekerasan dengan berbicara baik-baik dengan orang lain.

5. Klien dapat mengendalikan Risiko Perilaku Kekerasan dengan melakukan spritual terjadwal. 


\section{BAB 5 \\ PENUTUP}

\subsection{Kesimpulan}

Setelah menguraikan tentang proses keperawatan Ny. T dan disimpulkan bahwa pasien dapat mengontrol risiko perilaku kekerasan dengan terapi yang di ajarkan. Dimana pasien dapat melakukan tarik nafas dalam, memukul bantal secara mandiri untuk mengontrol amarahnya. Pasien juga minum obat secara teratur dan berbicara secara baik-baik jika ingin meminta sesuatu atau melakukan penolakan, hingga pasien dapat melakukan spritual sesuai ajaran agama yang dianut.

\subsection{Saran}

1. Bagi pasien hendaknya dapat mengontrol emosi dengan menerapkan strategi pelaksanaan, mengontrol perilaku kekerasan dengan cara tarik nafas dalam dan pukul bantal kasur, minum obat secara teratur, latihan cara komunikasi secara verbal atau bicara baik-baik, dan spiritual untuk mendukung kelangsungan kesehatan pasien.

2. Bagi Yayasan Pemenang Jiwa hendaknya memberikan pelayanan kesehatan yang baik dan membuat suasana lingkungan menjadi lebih nyaman agar klien tidak melakukan risiko perilaku kekerasan. Usahakan memberikan saran, nasehat dan motivasi kepada klien agar klien mendapatkan cara tentang bagaimana mengontrol marah. 


\section{DAFTAR PUSTAKA}

Wulansari, E. M. \& Sholihah, M, M. (2021). Asuhan Keperawatan Jiwa Pada Pasien Dengan Resiko Perilaku Kekerasan Dirumah Sakit Daerah Dr Arif Zainuddin Surakarta (Doctoral dissertation, Universitas Kusuma Husada Surakarta). http://eprints.ukh.ac.id/id/eprint/1020

Kandar, K., \& Iswanti, D. I. (2019). Faktor Predisposisi dan Prestipitasi Pasien Resiko Perilaku Kekerasan. Jurnal Ilmu Keperawatan Jiwa, 2(3), 149156. http://dx.doi.org/10.32584/jikj.v2i3.226

Kio, A. L., Wardana, G. H., \& Arimbawa, A. G. R. (2020). Hubungan Dukungan Keluarga terhadap Tingkat Kekambuhan Klien dengan Resiko Perilaku Kekerasan. Caring: Jurnal Keperawatan, 9(1), 69-72. http://ejournal.poltekkesjogja.ac.id/index.php/caring/article/view/592

Makhruzah, S., Putri, V. S., \& Yanti, R. D. (2021). Pengaruh Penerapan Strategi Pelaksanaan Perilaku Kekerasan terhadap Tanda Gejala Klien Skizofrenia di Rumah Sakit Jiwa Daerah Provinsi Jambi. Jurnal Akademika Baiturrahim Jambi, 10(1), 39-46. http://dx.doi.org/10.36565/jab.v10i1.268

Pardede, J. A., Siregar, L. M., \& Hulu, E. P. (2020). Efektivitas Behaviour Therapy Terhadap Risiko Perilaku Kekerasan Pada Pasien Skizofrenia Di Rumah Sakit Jiwa Prof. Dr. Muhammad Ildrem Provsu Medan. Jurnal Mutiara Ners, 3(1), 8-14. http://114.7.97.221/index.php/NERS/article/view/1005

Pardede, J. A., \& Laia, B. (2020). Decreasing Symptoms of Risk of Violent Behavior in Schizophrenia Patients Through Group Activity Therapy. Jurnal Ilmu Keperawatan Jiwa,3(3), 291-300. http://journal.ppnijateng.org/index.php/jikj/article/view/621/338

Pardede, J. A. (2020, November 12). Standar Asuhan Keperawatan Jiwa Dengan Masalah Risiko Perilaku Kekerasan. https://doi.org/10.31219/osf.io/we7zm

Pardede, J. A., Keliat, B. A., \& Wardani, I. Y. (2013). Pengaruh Acceptance And Commitment Therapy Dan Pendidikan Kesehatan Kepatuhan Minum Obat Terhadap Gejala, Kemampuan Berkomitmen Pada Pengobatan Dan Kepatuhan Pasien Skizofrenia. Tesis.FIK UI.Depok

Pitayanti, A., \& Hartono, A. (2020). Sosialisasi Penyakit Skizofrenia Dalam Rangka Mengurangi Stigma Negatif Warga di Desa Tambakmas Kebonsari-Madiun. Journal of Community Engagement in Health, 3(2). https://jceh.org/index.php/JCEH/article/view/83/78 
Dwi Prastya, F., \& Arum Pratiwi, S. K. (2017). Mekanisme Koping Pada Pasien Perilaku Kekerasan Dengan Risiko Menciderai Orang Lain Dan Lingkungan (Doctoral dissertation, Universitas Muhammadiyah Surakarta). http://eprints.ums.ac.id/id/eprint/52420

Riskesdas (2018) Hasil Utama riskesdas 2018 Kementrian Kesehatan Badan Penelitian dan Pengembangan Kesehatan.

Untari, S. N. (2021). Asuhan keperawatan jiwa pada pasien dengan resiko perilaku kekerasan (Doctoral dissertation, Perpustakaan Universitas Kusuma Husada Surakarta). http://eprints.ukh.ac.id/id/eprint/961

Hasannah, S. U. (2019). Asuhan Keperawatan Jiwa pada Pasien Dengan Risiko Perilaku Kekerasan (Doctoral dissertation, STIKes Kusuma Husada Surakarta). http://eprints.ukh.ac.id/id/eprint/41

Nadek, V. F. (2019). Asuhan Keperawatan Jiwa Pada Pasien Dengan Diagnosa: Perilaku Kekerasan Diruang Rawat Inap Naimata Kupang (Doctoral dissertation, Poltekkes Kemenkes Kupang). http://repository.poltekeskupang.ac.id/1851/1/KTI_\%28VERDIANA_N ADEK\%29.pdf

Anggit Madhani, A. (2021). Asuhan Keperawatan Jiwa Pada Pasien Dengan Resiko Perilaku Kekerasan (Doctoral dissertation, Universitas Kusuma Husada Surakarta). http://eprints.ukh.ac.id/id/eprint/922/1/P17D\%20NASPUB\%2019\%2020 \%20ANGGIT\%20MADHANI_P17160.pdf

Hastuti, R. Y., Agustina, N., \& Widiyatmoko, W. (2019). Pengaruh restrain terhadap penurunan skore panss EC pada pasien skizofrenia dengan perilaku kekerasan. Jurnal Keperawatan Jiwa, 7(2), 135-144. https://jurnal.unimus.ac.id/index.php/JKJ/article/view/4907/pdf

Mulia, D. D. P. B. (2020). Penatalaksanaan Secara Konstruktif Dengan Crossword Puzzle Pasien Risiko Perilaku Kekerasan di RSJD dr. Arif Zainudin Surakarta. IJMS-Indonesian Journal on Medical Science, 7(2). http://ejournal.ijmsbm.org/index.php/ijms/article/view/246

Saputri, S. F. M \& Mar'atus, M. (2021). Asuhan Keperawatan Jiwa Dengan Resiko Perilaku Kekerasan. Skripsi, Universitas Kusuma Husada Surakarta.

Wardani, L. K., \& Sari, D. K. (2018). Analisa Kemampuan Mengontrol Marah ditinjau dari Penerapan REBT (Rational Emotive Behaviour Theraphy) pada Klien Skizofrenia di UPT Bina Laras Kras Kediri. STRADA Jurnal Ilmiah Kesehatan, 7(2), 57-61. https://doi.org/10.30994/sjik.v7i2.173 
Lovinda Pristalia, (2021). Asuhan Keperawatan Jiwa Pada Pasien Dengan Resiko Perilaku Kekerasan. Karya Tulis Ilmiah, Universitas Kusuma Husada Surakarta.http://eprints.ukh.ac.id/id/eprint/985/1/Naspub\%20LOVINDA. pdf 